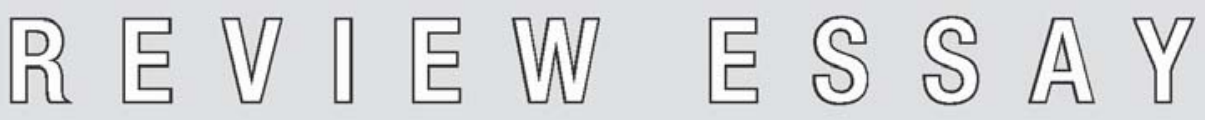
af Peter Abrahamson

\title{
Den skandinaviske velfærdsmodel i historisk og sociologisk belysning: I deal, eksportartikel eller unik?
}

E. Carrol, og J. Palme: Inclusion of the European "Nordic Model" in the Debate Concerning Reform of Social Protection: the Long-Term Development of Nordic Welfare Systems 1890 - 2005 and their Transferability to Latin America of the $21^{\text {st }}$ Century. Santiago de Chile: United Nations: Economic Commission for Latin America and the Caribbean. Serie: Financiamiento del Desarrollo \# 168, 2006.

N. F. Christiansen, K. Petersen, N. Edling, P. Haave (red.): The Nordic Model of Welfare: an Historical Reappraisal. Copenhagen: Museum Tusculanum Pres, 2006.

S. Kuhnle, og S. E. Hort: The Developmental Welfare State in Scandinavia: Lessons for the Developing World. Geneva: United Nations Research Institute for Social Development. Social Policy and Development Programme Paper Number 17, 2004.

Den skandinaviske velfærdsmodel er for længst blevet et begreb inden for socialvidenskaberne, endskønt den har mange navne såsom nordisk (Christiansen et al. 2006), socialdemokratisk (Esping-Andersen 1990), institutionelomfordelende (Titmuss 1971), social servicestat (Sipillä et al. 1997), udviklende (Kuhnle og Hort 2004) eller omfattende (Korpi og Palme 1998). På trods 
af denne uenighed om, hvad barnet skal hedde, er der bred enighed om mange af de karakteristika, der forbindes med modellen: den er rettighedsbaseret og knyttet til (lovligt) ophold inden for nationalstaten; den er overvejende finansieret via skatter; hovedvægten ligger på offentlige overførsler og ikke mindst tjenesteydelser; den er omfordelende; og den både muliggør og forudsætter en høj arbejdsmarkedsdeltagelse for begge køn (og mange aldre) (Abrahamson 1999, 2005; Palme 1999; Swank 2000). Disse karakteristika er blevet sammenfattet som: solidarisk, universel og rettighedsbaseret. Men der er også elementer, som socialvidenskabsfolk, historikere og sociologer har været uenige om, hvoraf de måske to mest centrale har været spørgsmålet om arbejderbevægelsernes og særligt socialdemokratiernes rolle og indflydelse på udviklingen af den skandinaviske model og spørgsmålet om stiafhængighed, altså hvorvidt de historisk tidlige måder at regulere, finansiere og udføre velfærdsmæssige foranstaltninger på begrænser eller besværliggør senere forsøg på radikale ændringer.

Der er måske nok nogle, der vil hævde, at disse spørgsmål stadigvæk er uløste, men med udgivelsen af bogen The Nordic Model of Welfare: an Historical Reappraisal, som er resultatet af et omfattende forskningssamarbejde blandt en række nordiske historikere, er der leveret et vægtigt og vigtigt bidrag til belysningen af den skandinaviske models udvikling. Projektet blev gennemført i perioden 1996 til 2003 og foreligger nu afrapporteret i form af denne bog, redigeret af de to danske historikere Niels Finn Christiansen og Klaus Petersen samt svenskeren Nils Edling og nordmanden Per Have. Ialt 10 forfattere har skrevet kapitler til bogen og endnu flere har medvirket i projektet undervejs. Som historikere har de været tæt på originale kilder, men de er også velinformeret af den sociologiske diskussion omkring velfærdsstatens udvikling i Norden og citerer den flittigt.

Samtidig er der bl. a. på initiativ af den svenske bistandsorganisation SIDA - blevet iværksat en række projekter om den historiske udvikling af den skandinaviske model i et udviklingsøjemed. Disse projekter er blevet afrapporteret af skandinaviske sociologer og politologer og heri diskuteres de samme temaer omkring arbejderbevægelsens rolle og stiafhængighed (Caroll og Palme 2006; Kuhnle og Hort 2004).

Fælles for disse projekter er en historisk-institutionel eller historie-sociologisk tilgang til analysen af den skandinaviske velfærdsstat, og det demonstreres overbevisende, at den er et resultat af et udstrakt samarbejde og kompromisser på tværs af klasseskel. Historikerne modererer således forestillingen om den nordiske model som et socialdemokratisk projekt, som det jo ellers er blevet promoveret vidt og bredt af den danske frivilligt eksilerede sociolog Gøsta Esping-Andersen (1990). Niels Finn Christiansen og Klas Åmark opsummerer: 
I de tidlige epoker lagde bønderne, andre småborgerlige grupper og endda dele af borgerskabet og deres politiske partier grunden for hvad der senere udviklede sig til velfærdssystemer. Universalisme, skattefinansiering og statsintervention er ikke socialdemokratiske opfindelser (2006:351).

De viser også, at de nordiske lande var "sent udviklede“" (latecomers), og at de i de første epoker ikke adskilte sig fra udviklingen i de øvrige europæiske lande. Først med velfærdsstatens guldalder (the golden age of welfare, les trente glorieuse), de tredive glorværdige år fra afslutningen af Anden Verdenskrig og til den første oliekrise i midten af 1970'erne stadfæstedes de for Norden særlige træk: "Efter den anden Verdenskrig blev de nordiske ordninger endeligt helt universelle, omfattende alle borgere" (Kuhnle og Hort 2004:7). Der er i denne litteratur enighed om, at de skandinaviske velfærdsinstitutioner udviklede sig graduelt og i de første to perioder (1870'erne til 1918 og mellemkrigstiden) ikke adskilte sig radikalt fra udviklingen i det øvrige Europa.

Foruden hvad der er nævnt ovenfor, fremhæves kvindernes centrale rolle. Der er en tæt sammenhæng mellem formaliseringen af kvinders arbejde og udviklingen af velfærdsinstitutioner. Kvinders stigende erhvervsfrekvens er således både en konsekvens af og en forudsætning for velfærdsstaten. Med udviklingen af velfærdsinstitutioner muliggjordes kvinders erhvervsarbejde, i og med at pasnings- og socialiseringsopgaver kollektiviseredes og frigjorde dem fra disse. Samtidig fandt store dele af væksten i kvinders arbejde sted inden for velfærdsinstitutionerne, hvor de fandt arbejde som pædagoger, lærere, sundhedspersonale og socialarbejdere. Disse perspektiver er specielt understreget i Inger Elisabeth Haavets bidrag: "Family policy formation in Norway and neighboring countries in the Twentieth Century;" $i$ Riita Oittinens bidrag: "Welfare, Health and Working Class Women in early 20th century Finland" og i Klas Åmarks bidrag: "Women's labor force participation in the Nordic countries During the Twentieth Century". Foruden klasse(samarbejds)perspektivet og kønsperspektivet er projektet også meget opmærksom på den tredje stratifikationskomponent: etnicitet. Det tillægges stor betydning, at befolkningerne i Norden var meget homogene i kulturel forstand: Vi deler en fælles historie, et fælles sprog (med Finland som vigtig undtagelse) og en fælles religion - protestantismen.

Et andet vigtigt moment, som historikerbogen har et skarpt øje for, er betydningen af regionalt samarbejde. Dette kommer særligt tydeligt frem i Klaus Petersens bidrag: "Constructing Nordic welfare? Nordic social political cooperation 1919 - 1955" og i Urban Lundbergs bidrag: "A leap in the dark: the joint committee of the Nordic social democratic labour movement and the crisis of the Nordic model". Petersen viser, hvordan institutionaliseringen af nordisk samarbejde omkring udviklingen af socialpolitik bidrog væsentligt til dennes homogenisering og udvikling. Dette perspektiv er overordentligt 
centralt i forhold til den aktuelle periode af globaliseringen, som jo netop er karakteriseret ved regionalisering (Yeates 2005; Yeates and Deacon 2006). Selvom regionaliseringen i første omgang antager form af øget handelssamkvem, så er det vurderingen hos denne anmelder, at udviklingen af de institutioner, der skal garantere frihandelssamarbejde, kan blive en løftestang for en større hensyntagen til sociale rettigheder og dermed udviklingen af velfærdsinstitutioner (Abrahamson 2007a).

En af de vigtigste erfaringer fra den skandinaviske udvikling er, at udviklingen af en omfattende velfærdsstat og økonomisk vækst ikke er modsætninger, men foregik hånd $\mathrm{i}$ hånd, og at velfærdsinstitutionerne har nydt og nyder stor opbakning i befolkningen. Den skandinaviske velfærdsstat har en høj grad af legitimitet.

Kuhnle og Hort fremhæver følgende elementer fra den skandinaviske politiske udvikling som mulig inspiration for mindre udviklede samfund: Selvom der eksisterede særlige strukturelle forudsætninger for udviklingen af en konsensus- og deltagelseskultur, så udelukker det ikke en vurdering af de mulige positive implikationer af universalismeprincippet i forhold til det generelle velfærdsniveau; den store vægt, der lå på socialplanlægning i første halvdel af det 20nde århundrede, var helt klart en del af en afbalancering af målene om økonomisk vækst og social retfærdighed; i alle de skandinaviske lande udviklede velfærdsforanstaltningerne sig gradvist fra i begyndelsen kun at omfatte dele af befolkningerne; det tillægges stor vigtighed, at vi i Skandinavien tidligt udviklede et universelt uddannelses- og sundhedssystem; økonomisk sikkerhed via socialforsikring reducerer arbejderes og arbejdsgiveres modstand mod forandring og faciliterer arbejdsmarkedsmobilitet, strukturel økonomisk forandring og vækst; social sikkerhed fungerer som en støddæmper i forhold til økonomiske (udefrakommende) chok; endelig fremhæves den omfattende offentlige omsorg for ældre, syge og børn som inspiration for andre lande. Disse elementer af en både familie- og arbejdsvenlig velfærdsstat kan dog i andre politiske kulturer opfattes som kontroversielle, medgives det. Kuhnle og Hort afslutter deres rapport med at konstatere, at velfærdsstater der er mere kønssensitive er de mest succesfulde både i forhold til økonomisk udvikling og social ro og harmoni (2004:21-23.)

Errol Caroll og Joakim Palmes historiske analyse af den skandinaviske velfærdsstatsudvikling er fuldstændig parallel til, hvad vi så hos Kuhnle og Hort, men i anbefalingerne er den mere specifik, idet den er rettet mod Latinamerika (LA). De konkluderer, at selvom der er væsentlige forskelle i den politiske historie i Skandinavien og Latinamerika, så er de ikke uoverstigelige. Og BNP per indbygger i Norden var lavt, da vi begyndte at opbygge velfærdsstaten; og niveauet i LA er nu på linie med, hvad det var i Norden i 1950'erne, som jo netop var det tidspunkt, hvor de store reformer satte ind. Mht. finansiering vurderer de, at LA ville kunne vinde meget ved at nedtone bidragssystemer og opprioritere skattefinansiering, og at en sådan bevægelse kan legitimeres 
som en form for udgiftskontrolmetode. De skandinaviske erfaringer peger også på, at den aktuelle dominerende målretning af ydelser i LA er kritisabel. Carroll og Palme konkluderer ud fra de skandinaviske erfaringer, at økonomisk åbenhed til omverdenen ikke er uforeneligt med social udvikling, tværtimod (2006: 56-59).

Spørgsmålet om de skandinaviske landes store økonomiske åbenhed er ofte diskuteret inden for små-lande-tesen (Katzenstein 1985; 2003; Kosonen 2004; Pierson 2004) som siger, at små åbne økonomier udvikler korporative politiske træk og omfattende velfærdsforanstaltninger til at kompensere for konsekvenserne af udefrakommende økonomiske chok. Men denne tese har tilsyneladende sin geopolitiske begrænsning til Europa (og - måske - Ny Zealand), idet den helt klart ikke gælder i fx. Mellemamerika (Abrahamson 2007b). Centralamerika og store dele af LA består af små åbne økonomier, men har, med delvis undtagelse af Costa Rica og Chile, undladt at udvikle omfattende velfærdsforanstaltninger. Der er således nogle grænser eller forudsætninger for at kunne overtage vores erfaringer.

Sammenfattende mht. hvilke betingelser, der skal være til stede for at kunne eksportere den skandinaviske model til Tredjeverdenslande, kan nævnes: De skandinaviske lande bestod af etnisk og religiøst homogene befolkninger; vi deler en opfattelse af staten som "os" og som garant for retfærdighed og ligebehandling; vi har udviklet en politisk kultur domineret af kompromis og konsensus; og vi har udviklet en omfattende deltagelse på et organiseret arbejdsmarked. Hermed er også givet begrænsningerne for "eksportstrategien". De fleste tredjeverdenslande har desværre ikke en lang demokratisk tradition; de er ikke homogene hverken mht. etnicitet eller religion; staten forbindes ofte, og med rette, med ineffektivitet, korruption og endog folkemord; størstedelen af befolkningen er beskæftiget inden for den informelle sektor og er således unddraget beskatning og regulering.

Med disse tre historie-sociologiske projekter er der givet et godt grundlag for forståelsen af den skandinaviske model, uanset om diskussionen går på dens modernisering og udvikling i denne region eller i forhold til, at den kan virke som inspiration for lande, der er i færd med at udvikle mere omfattende velfærdsforanstaltninger.

Peter Abrahamson

E-mail: pa@soc.ku.dk

\section{Litteratur}

Abrahamson, P. 1999: "The Scandinavian Model of Welfare". In D. Bouget \& B. Palier (ed.): Comparing Social Welfare Systems in Nordic Europe and France. Paris: MIREDRESS, pp. 31-60.

Abrahamson, P. 2005: "La fin de modèle Scandinave?" Revue française des Affaires Sociales. Vol. 59, No. 3:105-127. 
Abrahamson, P. 2007a: "Free Trade and Social Citizenship: Prospects and Possibilities of the Central American Free Trade Agreement (CAFTA-DR)“. Global Social Policy Vol. 7 No. 3:339-357.

Abrahamson, P. 2007b: "Política Fiscal y Protección Social en Estados Pequeños: Comparando Escandinavia y Centroamérica". Boletín de Estudios Fiscales No 7:537.

Esping-Andersen, G. 1990: The Three Worlds of Welfare Capitalism. Cambridge: Polity Press.

Katzenstein, P. J. 1985: Small States in World Markets: Industrial Policy in Europe (Cornell Studies in Political Economy). Ithaca: Cornell University Press.

Katzenstein, P. J. 2003: "Small States and small states revisited". New Political Economy Vol. 8 No. 1:9-30.

Korpi, Walter \& Joakim Palme 1998: "The Paradox of Redistribution and Strategies of Equality". American Sociological Review Vol. 63, No. 5:661-87.

Kosonen, P. 2004: "Small and large states in the face of internationalization and globalization". Paper prepared for presentation to the Cost Action 15 Conference. Nantes, May.

Palme, J. 1999: The Nordic model and the modernisation of social protection in Europe. Copenhagen: Nordic Council of Ministers.

Pierson, Ch. 2004: Late Industrializers and the Development of the Welfare State. Geneva: United Nations Research Institute for Social Development. Social Policy and Development Programme. Paper Number 16.

Sipilä, Jorma (ed.) 1997: Social Care Services: The Key to the Scandinavian Model. Aldershot: Avebury.

Swank, D. 2000: "Social democratic welfare states in a global economy". In R. Geyer; C. Ingebritsen; J. W. Moses (eds.): Globalization, Europeanization and the end of Scandinavian social democracy? London: Macmillan, pp. 85-138.

Titmuss, R. M. 1971 [1987]: “Developing social policy in conditions of rapid change: the role of social welfare". The Philosophy of welfare. London: Allen and Unwinn, pp. 254-68.

Yeates, N. 2005: "Globalization" and Social Policy in a Development context. UNRISD Programme on Social Policy and Development Paper Number 18. Geneva: United Nations Research Institute for Social Development.

Yeates, N. and Deacon, B. 2006: "Globalism, Regionalism and Social Policy: framing the debate", Working Paper, a revised version of a paper presented to the HighLevel Symposium on the Social Dimensions of Regionalism, Montevideo, Uruguay, February $21^{\text {st }}-23^{\text {rd }} 2006$, organized as part of the International Forum on the Social Sciences-Policy Nexus, UNESCO, Buenos Aires, $20^{\text {th }}-24^{\text {th }}$ February 2006. 